\title{
Economic Feasibility of Using Switchgrass Pasture to Produce Beef Cattle Gain and Bioenergy Feedstock
}

\author{
Jon T. Biermacher ${ }^{1}$ - Mohua Haque ${ }^{2} \cdot$ Jagadeesh Mosali $^{3}$ - James K. Rogers ${ }^{1}$
}

Published online: 12 May 2017

(C) The Author(s) 2017. This article is an open access publication

\begin{abstract}
Integration of switchgrass (Panicum virgatum L.) into livestock production systems has potential to improve farm economics and encourage development of a biofuel industry in the Southern Great Plains. The objectives of this study were to determine the economics of seven alternative switchgrass grazing and bioenergy feedstock systems and to determine how sensitive the results are among the systems for a range of cattle and feedstock prices. Data were collected from a completely randomized designed grazing study in south-central Oklahoma in 2008, 2009, and 2010. Stocking density treatments $\left[0,2.5,4.9\right.$ and $\left.7.4 \mathrm{hd} \mathrm{ha}^{-1}\right]$ were randomly assigned to 12 0.81-ha switchgrass pastures. Using biological data from the field trial, economic data collected from the marketplace and assumptions about prices of bioenergy feedstock, seven production systems were simulated. The systems included no-graze feedstock only (NG/FS); graze lightly no feedstock (GL/NF); graze moderately no feedstock (GM/NF); graze heavily no feedstock H/NF)]; lightly grazed
\end{abstract}

Jon T. Biermacher

jtbiermacher@noble.org

Mohua Haque

mohua.haque@gmail.com

Jagadeesh Mosali

mjagadeeshreddy@gmail.com

James K. Rogers

jkrogers@noble.org

1 The Samuel Roberts Noble Foundation, Inc., 2510 Sam Noble Parkway, Ardmore, OK 73401, USA

2 JPMorgan Chase, 1111 Polaris Pkwy, Columbus, OH 43240, USA

3 Mosali Consulting, LLC, 3967 Spinnaker Run Pt, Little Elm, TX 75068, USA plus feedstock (GL/F); moderately grazed plus feedstock $(\mathrm{GM} / \mathrm{F})$; and heavily grazed plus feedstock $(\mathrm{GH} / \mathrm{F})$. Enterprise budgeting was used to compute expected net returns for the seven systems. Random-effects mixed ANOVA models were used to determine the effects of production system on yield, gain, and net return. At a feedstock price $\$ 0 \mathrm{Mg}^{-1}$, the GM/NF was the most profitable $\left(\$ 45 \mathrm{ha}^{-1}\right)$ system. At feedstock prices of $\$ 55$ and $\$ 83 \mathrm{Mg}^{-1}$, the GL/F system realized net returns of $\$ 232$ and $\$ 523 \mathrm{ha}^{-1}$, respectively, and for feedstock prices $>\$ 83 \mathrm{Mg}^{-1}$, the NG/FS system was determined to be most economical.

Keywords Bioenergy economics · Stocker cattle grazing · Grazing season extension $\cdot$ Switchgrass

\section{Introduction}

Stocker cattle producers in the Southern Great Plains (SGP) graze stocker cattle on cool-season annual forages, typically winter wheat (Triticum aestivum L.) $[1,2]$ in the fall through the spring. Each year, more than 6 million young, lightweight calves are transported to this region from other parts of the country especially from the Southeast, Midwest, and West to be grazed on winter small grain pastures $[3,4]$. The majority of the acres planted to small grains in the SGP are typically established to wheat in early September to ensure that pasture is available for grazing by mid-November through the latter part of April [5]. Wheat is the typical variety of small grain established because it allows producers the option to produce pounds of gain on stocker cattle while also allowing them to produce a grain crop, provided cattle are removed from pasture before the development of the first hollow stem in late winter [6]. However, there are many producers who have land that is not well suited for growing grain who choose to 
establish small grain pasture for graze-only systems - systems that only produce pounds of beef without producing any grain. These producers will often times utilize a small grain variety (or a mix of varieties) other than wheat, including rye (Secale cereale L.), oats (Avena sativa L.), and triticale (X-Triticosecale L.) because these varieties have the ability to produce more fall, winter, and spring forage than wheat. It is also common for ranchers who engage in graze-only systems to include annual ryegrass (Lolium multiflorum Lam.) with small grain pasture because the growth cycle for ryegrass typically allows for an additional 30 days of grazing after small grain forage is grazed out in mid-April. After pastures are completely grazed out, calves are marketed to feedyards where they are fed to slaughter weight using grain-based diets [7]. Market prices may provide an economic incentive for cattle producers to extend the grazing season of cereal pastures in order to supply additional, lower cost gain to their calves prior to marketing them to a feedlot [8]. However, cattle producers face challenges associated with a foragedeficient gap between late April when cereal pasture is grazed out completely and late June when warm season perennial forages (e.g., bermudagrass) become abundant. This deficiency in forage availability along with market forces has provided an incentive for forage and livestock producers to search for economical management solutions to the traditional winter cereal forage grazing system.

Previous research suggests that the SGP - a region that has a comparative advantage in growing native perennial grasses for livestock, wildlife habitat, and conservation programs - has the potential to develop a large-scale cellulosic conversion industry [9, 10]. Switchgrass (Panicum virgatum L.) is a warm-season native perennial grass that has been identified as a potential source of cellulosic feedstock for the large-scale production of biofuel in the SGP $[11,12]$. Studies show that switchgrass has the ability to produce high yields in dry climates with low levels of precipitation and lower quantities of macronutrients like $\mathrm{N}$, making it an attractive candidate as a cellulosic bioenergy crop [13-15]. In addition to its agronomic potential as a bioenergy feedstock crop, a number of studies report that grazing early growing switchgrass produces good beef cattle gain. For instance, Burns, Mochrie, and Timothy [16] reported that switchgrass pastures evaluated in North Carolina maintained a long growing season and had a valuable impact on average daily gain. Mosali et al. [17] reported average daily gains ranging between 0.83 and $1.05 \mathrm{~kg} \mathrm{hd}^{-1}$ for stocker cattle grazing between early April and late May. These gains for this grazing period are ideally in line with the period of the year when cereal forage has been grazed out, leaving available forage for season extension in shortage.

At present, only a few studies have been published that report on the biological potential for using switchgrass for cattle grazing and bioenergy feedstock $[17,18]$. Mosali et al. [17] found from a 3-year field trial conducted in Oklahoma that switchgrass has the potential to extend the cereal pasture grazing season with high-quality forage while also allowing for the after-grazing regrowth to be produced into a bioenergy feedstock that can be marketed to a biorefinery as a high-quality source of bioenergy feedstock. However, despite the agronomic potential that switchgrass has been shown to have in the literature for both grazing and bioenergy purposes, studies reporting the economic potential of these purposes is limited to one study in Tennessee [19] and non-existent for the SGP.

The objectives of this study were to determine and compare the economics of seven alternative switchgrass grazing/ bioenergy feedstock systems that were designed to either extend the annual cereal forage grazing season only, extend the annual cereal forage grazing season plus produce bioenergy feedstock, or to produce only a bioenergy feedstock crop. We also determine how sensitive the relative results are over a range of prices of stocker cattle and bioenergy feedstock. Information gathered from this research will be useful in helping producers in this region make informed decisions about whether or not to establish switchgrass for grazing and feedstock production purposes. This study will also be valuable to biorefinery investors who are interested in ensuring a steady, long-term, and locally produced cellulosic feedstock in the region.

\section{Data and Methods}

\section{Study Site and Grazing Study}

Measures of feedstock yield and steer performance were collected from a 3-year (2008-2010) stocker cattle grazing study conducted at the Samuel Roberts Noble Foundation's Red River Research and Demonstration Farm near the community of Burneyville in south-central Oklahoma $\left(33^{\circ} 53^{\prime} \mathrm{N} / 97^{\circ} 17^{\prime} \mathrm{W}\right)$. The experiment was a completely randomized design (CRD) with three replications and four treatments: one un-grazed control (feedstock only) and three individual stocking rates: light $\left(2.5\right.$ steers $\left.\mathrm{ha}^{-1}\right)$, moderate $\left(4.9\right.$ steers ha $\left.^{-1}\right)$, and heavy $\left(7.4\right.$ steers $\left.\mathrm{ha}^{-1}\right)$.

Twelve 0.81-ha switchgrass pastures (experimental units) were established and used for the grazing experiment. In order to clean up winter annuals from cereal forage crops historically grown at the study site prior to the establishment of switchgrass, all paddocks received a single application of glyphosate [N-(phosphonomethyl) glycine] at a rate of $2.34 \mathrm{~L} \mathrm{ha}^{-1}$ before initiating the experiment. Paddocks were prepared for planting by a disking followed by field cultivation operation. "Alamo" switchgrass was planted 12 May 2007 at a rate of $4.5 \mathrm{~kg}$ PLS $\mathrm{ha}^{-1}$ into a clean-tilled prepared seedbed. Switchgrass plants 
emerged and were left to grow until July, followed by a mowing operation when switchgrass plants reached a height of $30 \mathrm{~cm}$. Outbreaks of pigweed (Amaranthus palmeri) were controlled by using a single application $\left(3.51 \mathrm{~L} \mathrm{ha}^{-1}\right)$ of 2,4-D amine (2,4-dichlorophenoxyacetic acid, dimethyl amine). No fertilizer was applied in the establishment year to reduce weed competition [20]. Prior to grazing initiation in each year of the study, each paddock was soil tested. Soil test results indicated adequate levels of phosphorus and potassium. Based on the results of the soil test, all plots received $78 \mathrm{~kg} \mathrm{ha}^{-1}$ year $^{-1}$ of $\mathrm{N}$ in the form of urea (46-0-0) before grazing initiation in the spring. This is the recommended $\mathrm{N}$ rate for "Alamo variety" for this region [21, 22]. All paddocks were harvested at the end of the growing season each year (2008-2010) at physiological maturity. Sub-samples of the harvested switchgrass were collected on each plot to calculate dry matter yield.

Steers used in this trial were purchased from local sale barns every year in September and were back-grounded for 42 days and had grazed a mixture of cool-season cereal rye/ryegrass (Secale cereale L./Lolium multiflorum Lam.) for at least 100 days (mid-November to early April) before turnout on switchgrass pasture. Grazing was initiated each year when grass height across all treatments was $\geq 36 \mathrm{~cm}$. Average animal weight, at the time of grazing initiation, was $347 \mathrm{~kg}$. Steers were removed from the pasture when the forage was grazed down to $\leq 7.5 \mathrm{~cm}$ or forage nutritive value became too low as it limited the animal growth [23, 25]. On average, pastures were stocked with the animal (steers, $n=36$ ) on 29 April and removed on average on 19 July, 11 June, and 27 May based on light, moderate, and heavy stocking rates, respectively. While on trial, steers were given free access to water and a salt/mineral mixture (A and $\mathrm{M}$ Monensin mineral medicated, Stillwater Milling Company) that contained Monensin $\left(1620 \mathrm{~g} \mathrm{~T}^{-1}\right)$. All animals were weighed after a 16-h withdrawal from feed and water at the beginning and end of grazing period.

Comprehensive details regarding switchgrass growing conditions, feedstock yield, animal management, and data measurement for the alternative stocking rates are reported in Mosali et al. [17].

\section{Switchgrass Grazing/Bioenergy Feedstock Systems}

Using biological data collected in the experiment for switchgrass bioenergy feedstock yields and animal performance, seven alternative switchgrass grazing/bioenergy feedstock systems were developed. The seven switchgrass grazing/bioenergy feedstock systems are considered to serve as potential options for extending the small grain pasture graze-only system common to the SGP. The seven switchgrass grazing/bioenergy feedstock options include a feedstock-only system [no graze, feedstock only (NG/F)]; three no feedstock, graze-only systems [grazed lightly, no feedstock (GL/NF); grazed moderately, no feedstock (GM/NF); grazed heavily, no feedstock $(\mathrm{GH} / \mathrm{NF})]$; and three graze plus feedstock systems [grazed lightly plus feedstock $(\mathrm{GL} / \mathrm{F})$; and grazed moderately plus feedstock $(\mathrm{GM} / \mathrm{F})$ and grazed heavily plus feedstock $(\mathrm{GH} / \mathrm{F})]$. Three no feedstock, graze-only systems (GL/NF, GM/NF, and $\mathrm{GH} / \mathrm{NF}$ ) were also evaluated resting squarely on the realization that a biorefinery does not exist in the area (i.e., a $\$ 0 \mathrm{Mg}^{-1}$ price of feedstock). For these three switchgrass systems, it was assumed that post-grazing regrowth would not need to be mechanically harvested (cut, raked, and baled) but would need to be removed to ensure a healthy stand development and growth of switchgrass plants in the subsequent year. We assume that a farmer would likely just mow the regrowth with a brush mower, which would be significantly less costly than cutting, raking, and baling the regrowth into packaged hay each year of the grazing trial.

\section{Economics}

Enterprise budgeting techniques were used to estimate expected values for costs, revenue, and net return for all seven grazing/feedstock systems [24]. Budgets included costs of establishing switchgrass and annual maintenance for all seven systems. Establishment costs included costs of seedbed preparation using a disc and a cultivator, costs of herbicide (glyphosate and 2,4-D amine) and its application, and the costs of seed and seed establishment. Estimated stand life for switchgrass was assumed to be 10 years and so the estimated total cost of establishing switchgrass stands was amortized over 10 years at a $7.5 \%$ annual interest rate.

Cost of annual maintenance activities of all seven switchgrass systems included $\mathrm{N}$ fertilizer and fertilizer application, herbicide (2,4-D amine) and herbicide application, harvesting activity, and annual operating interest. Cost of harvest activities (mowing, raking, baling into large (561 kg) round bales and hauling and stacking) were included in the annual budget for the no-graze feedstock only $(\mathrm{NG} / \mathrm{F})$ and for three graze plus feedstock systems (GL/F, GM/F, and GH/F). Cost of mowing and raking does not vary between systems as it is estimated on a per hectare basis; however, the cost of baling, hauling, and stacking varies between systems as it is a function of yield $[11,26]$. A custom rate of $\$ 34.86 \mathrm{ha}^{-1}$ was used for the cost associated with mowing post-grazing forage regrowth in the budgets for the three graze-only systems. Our assumption here is that mowing the regrowth will not have an impact on future cattle performance or post-grazing regrowth. Of course, this assumption is bold because we cannot be certain that mowing 
regrowth with a brush mower sometime after plant senescence and before switchgrass emergence in the spring will not affect future growth and quality. However, using the cost associated with cutting, raking, and bailing the regrowth (an average of $\$ 390 \mathrm{ha}^{-1}$ for the four systems that produced feedstock) also does not seem reasonable, even though it was the method actually used to remove regrowth in the trial.

The initial costs associated with owning and preparing steers for cool season grazing of the small grain rye plus ryegrass pasture (i.e., preconditioning expenses such as feed, vaccinations, castration of bull calves, dehorning, ear tags, death loss, etc.) have been accounted for in the cereal forage grazing phase of the stocker cattle production system. However, the opportunity cost of using capital to own the steers during the switchgrass grazing phase of the system needs to be accounted for as an operating cost. This cost per hectare is calculated by multiplying the value of the steer at the beginning of the switchgrass grazing phase by the stocking rate $\left(\mathrm{hd} \mathrm{ha}^{-1}\right)$ times the grazing duration times the daily interest rate (i.e., grazing duration divided by 365 times the annual interest rate). For example, if a steer weighing $362 \mathrm{~kg}$ is worth $\$ 2.60 \mathrm{~kg}^{-1}$ on 29 April (the initial cattle placement date for switchgrass grazing), then its initial value would be $\$ 941$. If we assume the stocking rate is 2 steers per hectare, the interest rate on an operating loan is 7.5 APR and the grazing duration is 50 days, then the opportunity cost of capital associated with owning the steers during the switchgrass grazing phase would be $\$ 19.76$ (or, $\$ 941 \times 2 \times 0.14 \times 0.075$ )

Custom rates were used to estimate costs associated with machinery operations for establishment activities [disking $\left(\$ 29.65 \mathrm{ha}^{-1}\right)$, cultivating $\left(\$ 18.53 \mathrm{ha}^{-1}\right)$, seed planting $\left(\$ 32.12 \mathrm{ha}^{-1}\right)$, mowing switchgrass stands $\left(\$ 34.86 \mathrm{ha}^{-1}\right)$ ] and for harvest activities [mowing switchgrass in baling process $\left(\$ 25.17 \mathrm{ha}^{-1}\right)$, raking $\left(\$ 9.59 \mathrm{ha}^{-1}\right)$, baling $\left(\$ 36.18 \mathrm{ha}^{-1}\right)$, and hauling and stacking $\left(\$ 11.12 \mathrm{ha}^{-1}\right)$. A rate of $\$ 14.83 \mathrm{ha}^{-1}$ was used for fertilizer and herbicide applications. Custom rates were obtained from Oklahoma Cooperative Extension Service [27]. Retail prices of $\$ 1.21 \mathrm{~kg}^{-1}$ of $\mathrm{N}$ (urea, 46-0-0), $\$ 33.07 \mathrm{~kg}^{-1}$ for switchgrass seed, $\$ 3.95 \mathrm{~L}^{-1}$ for herbicide glyphosate, and $\$ 5.03 \mathrm{~L}^{-1}$ for herbicide 2,4-D amine were obtained from local farm input suppliers. A complete list of production activity expenses for each switchgrass grazing/ bioenergy feedstock system is reported in Table 1 .

Cattle placement dates and placement weights were similar for each grazing treatment; however, cattle removal (sell) dates, removal (sell) weights, and total gain per hectare varied significantly between light, moderate, and heavy stocking rate treatments (Table 2). As a result, the price one would expect to receive per kilogram of total gain, often referred to as value of gain (VOG), would likely be different between grazing treatments. VOG is calculated as the difference between the beginning and ending value of a steer divided by the total amount of gain accumulated on the steer during the grazing period. More formally, VOG for an individual steer is defined as

$V O G_{i}=\left(\frac{\operatorname{EndPr}_{i}{ }^{*} \operatorname{EndWt}_{i}-\mathrm{BegPr}_{i}{ }^{*} \mathrm{BegWt}_{i}}{\mathrm{GAIN}_{i}}\right)$

where $B e g P r$ and $E n d P r$ represent the price $\left(\$ \mathrm{~kg}^{-1}\right)$ of an individual steer, $i$, at the beginning and ending of the grazing period, respectively; BegWt and EndWt represent the total live

Table 1 Production activity expenses by switchgrass grazing/bioenergy feedstock system $\left(\$ \mathrm{ha}^{-1}\right)$

\begin{tabular}{|c|c|c|c|c|c|c|c|}
\hline \multirow[b]{2}{*}{ Production activity } & \multicolumn{7}{|c|}{ Switchgrass grazing/feedstock system } \\
\hline & GL/NF & $\mathrm{GM} / \mathrm{NF}$ & $\mathrm{HG} / \mathrm{NF}$ & $\mathrm{GL} / \mathrm{F}$ & $\mathrm{GM} / \mathrm{F}$ & $\mathrm{GH} / \mathrm{F}$ & $\mathrm{NG} / \mathrm{F}$ \\
\hline Establishment cost & 332 & 332 & 332 & 332 & 332 & 332 & 332 \\
\hline Establishment cost amortized over 10 years at 7.5 APR & 47 & 47 & 47 & 47 & 47 & 47 & 47 \\
\hline \multicolumn{8}{|l|}{ Annual maintenance expenses } \\
\hline Fertilizer $\mathrm{N}(46-0-0)$ and $\mathrm{N}$ application & 126 & 126 & 126 & 126 & 126 & 126 & 126 \\
\hline Herbicide (2,4-D amine) for pigweed control & 33 & 33 & 33 & 33 & 33 & 33 & 33 \\
\hline Cut, rake, bale and stack switchgrass feedstock & - & - & - & 394 & 311 & 299 & 557 \\
\hline Mow off post-grazing switchgrass regrowth & 35 & 35 & 35 & - & - & - & - \\
\hline Interest on capital used for fertilizer and herbicide & 4 & 4 & 4 & 4 & 4 & 4 & 4 \\
\hline Interest on operating capital used for cattle ownership & 41 & 44 & 43 & 41 & 44 & 43 & - \\
\hline Total annual maintenance and harvest costs & 239 & 241 & 240 & 597 & 517 & 505 & 720 \\
\hline Total establishment, maintenance and harvest costs & 286 & 288 & 287 & 644 & 564 & 552 & 767 \\
\hline
\end{tabular}

$G L / N F$ graze lightly, no feedstock, $G M / N F$ graze moderately, no feedstock, $G H / N F$ graze heavily, no feedstock, $G L / F$ graze lightly plus feedstock, $G M / F$ graze moderately plus feedstock, $G H / F$ graze heavily plus feedstock, $N G / F$ feedstock only systems 
Table 2 Average feedstock yield, grazing dates, and animal performance for seven switchgrass grazing/bioenergy feedstock systems

Yield and animal performance $\quad$ Switchgrass grazing/feedstock system

\begin{tabular}{|c|c|c|c|c|c|c|c|c|}
\hline & \\
\hline & $\mathrm{GL} / \mathrm{NF}$ & $\mathrm{GM} / \mathrm{NF}$ & $\mathrm{HG} / \mathrm{NF}$ & $\mathrm{GL} / \mathrm{F}$ & $\mathrm{GM} / \mathrm{F}$ & $\mathrm{GH} / \mathrm{F}$ & $\mathrm{NG} / \mathrm{F}$ & $P>\mathrm{FS}^{\mathrm{a}}$ \\
\hline Yield $\left(\mathrm{Mg} \mathrm{ha}^{-1}\right)$ & - & - & - & $10.55 b$ & $8.11 \mathrm{c}$ & $7.77 \mathrm{c}$ & $15.34 \mathrm{a}$ & 0.0001 \\
\hline Average cattle placement & April 29 & April 29 & April 29 & April 29 & April 29 & April 29 & - & \\
\hline Average cattle market date & July 19 & June 11 & May 27 & July 19 & June 11 & May 27 & - & \\
\hline Stocking rates $\left(\mathrm{hd} \mathrm{ha}^{-1}\right)$ & 2.5 & 4.9 & 7.4 & 2.5 & 4.9 & 7.4 & 0 & \\
\hline Average daily gain $\left(\mathrm{kg}\right.$ day $\left.{ }^{-1} \mathrm{hd}^{-1}\right)$ & 0.83 & 1.04 & 1.05 & 0.83 & 1.04 & 1.05 & - & 0.1720 \\
\hline Grazing duration (day) & 81 & 43 & 28 & 81 & 43 & 28 & - & \\
\hline Steer grazing days & 203 & 215 & 210 & 203 & 215 & 210 & - & \\
\hline Total gain $\left(\mathrm{kg} \mathrm{ha}^{-1}\right)$ & 167 & 214 & 199 & 167 & 214 & 199 & - & 0.0803 \\
\hline
\end{tabular}

Means reported within a row followed by a common letter are not significantly different based on LSD test $(P \leq 0.05)$

$G L / N F$ graze lightly, no feedstock, $G M / N F$ graze moderately, no feedstock, $G H / N F$ graze heavily, no feedstock, $G L / F$ graze lightly plus feedstock, $G M / F$ graze moderately plus feedstock, $G H / F$ graze heavily plus feedstock, $N G / F$ feedstock only systems

${ }^{\text {a }} P$ values are based on Fisher's protected $F$-tests

body weight $\left(\mathrm{kg} \mathrm{hd}^{-1}\right)$ of steer $i$ at the beginning and end of the grazing period, respectively; and GAIN represents the total growth in weight $\left(\mathrm{kg} \mathrm{hd}^{-1}\right)$ realized by steer $i$ during the grazing period.

One of the challenges for stocker producers is trying to determine today what the value of gain will be for a grazing period in the future. The use of past cattle prices can be misleading because the cattle cycle is constantly changing by responding to a multitude of factors that are typically out of the control of producers [28]. For this study, we used a forward-looking approach to determine an expected base-case VOG for cattle grazing each treatment. Average placement and removal weights and dates observed for cattle for each treatment over the 3 years of the study were used in tandem with BeefBasis.com's Feeder Cattle Basis Forecasting Calculator to determine base-case values of gain for cattle for each treatment [29]. In January of 2013, we incorporated the animal data observed in the grazing trial (weights and dates) that was completed in mid-July of 2010 into the beef cattle forecasting tool in order to obtain 2013 estimates of beginning and ending value of the steers that grazed during the respective periods for each treatment. In other words, we asked the question: what would the VOG for cattle similar to what we used in the grazing trial that ended in 2010 be for the 2013 grazing season? Based on this approach, the base-case VOG for the 2013 grazing season were estimated to be $\$ 1.75, \$ 1.55$, and $\$ 1.29 \mathrm{~kg}^{-1}$ for the light, moderate, and heavy stocking rate treatments, respectively.

As of July of 2015, no large-scale cellulosic-based biorefinery that purchases bioenergy feedstock exists in the region; therefore, the farm-gate price of switchgrass feedstock was assumed to equal $\$ 0 \mathrm{Mg}^{-1}[8,28]$. Given the lack of an established market for switchgrass feedstock, previous researchers assumed alternative switchgrass feedstock prices (ranging from $\$ 30 \mathrm{Mg}^{-1}$ to $\$ 165 \mathrm{Mg}^{-1}$ ) when estimating expected profit from this enterprise [11, 25, 30]. In addition, a number of studies estimated breakeven price of switchgrass that ranges from $\$ 37 \mathrm{Mg}^{-1}$ to $\$ 98 \mathrm{Mg}^{-1}$ [31-33]. Given these results, switchgrass feedstock prices ranging from $\$ 0$ to $\$ 165 \mathrm{Mg}^{-1}$ were used to calculate net returns of systems for base and alternative cattle prices to see how robust results are under various price scenarios. Three different cattle price scenarios were used to conduct the sensitivity analysis, including (1) a base case, $30 \%$ increase, and 30\% decrease from the base VOG. It is noteworthy to mention that the choice of system depends mostly on cattle and feedstock prices. For example, at feedstock price of $\$ 0 \mathrm{Mg}^{-1}$, we can determine the most economical system only by comparing the three graze-only systems (GL/NF, GM/NF, and GH/NF). In contrast, when the price of feedstock is greater than $\$ 0 \mathrm{Mg}^{-1}$, it would be feasible to compare the economics of all seven switchgrass grazing/ bioenergy feedstock systems.

\section{Statistics}

Effects of treatment (stocking rate) on feedstock yield and measures of animal performance (average daily gain and total gain) and economic performance (net return) were analyzed using random-effects mixed ANOVA models using the PROC Mixed procedure in SAS [34, 35]. Stocking density treatment (light, moderate, and heavy) was considered as a fixed effect, and year was considered as a random effect. Fisher's protected $F$-test was used to test the hypothesis of no difference in feedstock yield, measures of animal performance, and net return between treatments. Least significant difference (LSD) tests were then used to scrutinize system means in order to identify the most economical grazing/feedstock system. 
Likelihood ratio (LR) tests were conducted to test null hypothesis of no year random effect for feedstock yield, animal performance, and economic net return [36, 37]. The LR test is based on the maximum likelihood ratio obtained from unrestricted and restricted mixed models analyzed with or without the year random effect. The test statistics (LR) follow a chi-square $\left(X^{2}\right)$ distribution with degrees of freedom equal to the number of restrictions imposed (i.e., one restriction in this case). If the test statistic (LR) $>X^{2}$ critical value at a $5 \%$ significant level, the null is rejected. The null hypothesis of no year random effect was rejected at $P<0.0001$ for feedstock yield ( $\mathrm{LR}=80.2$; $\left.X^{2}=3.84 ; \mathrm{j}=1\right), \operatorname{ADG}\left(\mathrm{LR}=69.6 ; X^{2}=3.84 ; \mathrm{j}=1\right)$, total gain $\left(\mathrm{LR}=10.0 ; X^{2}=3.84 ; \mathrm{j}=1\right)$, total cost $\left(\mathrm{LR}=382 ; X^{2}=3.84\right.$; $\mathrm{j}=1)$, total revenue $\left(\mathrm{LR}=7.6 ; X^{2}=3.84 ; \mathrm{j}=1\right)$, and net return $\left(\mathrm{LR}=4.8 ; X^{2}=3.84 ; \mathrm{j}=1\right)$.

\section{Results and Discussions}

Feedstock yield, grazing dates, and measures of animal performance for the alternative switchgrass grazing/ bioenergy feedstock systems are reported in Table 2. On average, feedstock yield differed $(P<0.0001)$ between switchgrass systems over the 3 -year period. The greatest yield of $15.34 \mathrm{Mg} \mathrm{ha}^{-1}$ was realized by the feedstock-only control system $(\mathrm{NG} / \mathrm{F})$. Previous studies reported similar results for switchgrass yields from un-grazed experiments conducted in the SGP $[15,22,23]$. The results also suggest that increasing stocking rates has an adverse effect on feedstock yield. For instance, 31, 47, and 49\% less feedstock yield were obtained from the systems with light (2.5 hd ha $\left.{ }^{-1}\right)$, moderate $\left(4.9 \mathrm{hd} \mathrm{ha}^{-1}\right)$, and heavy $\left(7.4 \mathrm{hd} \mathrm{ha}^{-1}\right.$ ) stocking rates, respectively, compared to the no-graze feedstock-only control treatment. Moreover, regrowth from the systems with light to heavy stocking rates (GL/ $\mathrm{F}, \mathrm{GM} / \mathrm{F}$, and $\mathrm{GH} / \mathrm{F}$ ) yielded approximately 51 to $69 \%$ of the no graze-feedstock only control yields. This result is similar to that found by Hintz, Moore, and Tarr [18] who reported switchgrass regrowth from grazing treatments (regardless of time of grazing) yielded approximately 55 to $65 \%$ of the no-grazing control treatment yields.

Average daily gains $0.83,1.04$, and $1.05 \mathrm{~kg} \mathrm{day}^{-1} \mathrm{hd}^{-1}$ for the light, moderate, and heavy stocked treatments, respectively, were not found to be different between grazing treatments $(P=0.1720)$. However, we point out that a limited number of years and replications of experimental units of this type of grazing study can limit the power of statistical testing. Numerically, our daily gains were similar to that found by Burns, Fisher, and Pond [38] who reported consistent and increased ADG due to increased stocking rates on switchgrass pasture. The lower gains for the lighter stocking rates were most likely due to a decrease in forage quality as the growing season progressed and because cattle expended more energy searching for the leaf portion of the plants. Because there were more cattle grazing the same area with the heavy stocking rate treatment, they were likely better able to keep up with the switchgrass growth compared to the fewer cattle grazing within the lighter stocked treatments, affording them the opportunity to consume higher-quality switchgrass. These arguments are consistent with findings from Anderson et al. [39] and Griffith and Jung [40].

Over the 3 years, total animal gain $\left(\mathrm{kg} \mathrm{ha}^{-1}\right)$ was not different $(P=0.0863)$ between the switchgrass grazing treatments at a $95 \%$ level of confidence but were at a $90 \%$ level. The numerical results in Table 1 suggest that an inverse relationship may exist between grazing duration and stocking rate. That is, the heavier the stocking rate, the fewer the number of days animals were able to graze before switchgrass was grazed down to a height of $7.5 \mathrm{~cm}$ and grazing was terminated. Grazing duration is relevant because it affects the opportunity cost associated with owning the steers during the switchgrass grazing phase of the switchgrass grazing/bioenergy feedstock system.

Estimates of net return to land, labor, overhead, and management for the seven switchgrass grazing/bioenergy feedstock systems under the base-case cattle price scenario are reported in Table 3. Results showed that net return differed $(p<0.0001)$ by switchgrass system depending on the price of feedstock. For instance, at a price of $\$ 0 \mathrm{Mg}^{-1}$ (no biorefinery), the most profitable system was the moderately grazed, no-feedstock system (GM/NF), which realized a $\$ 45 \mathrm{ha}^{-1}$ net return compared to the other grazeonly, no-feedstock systems (GL/NF and GH/NF). For a biorefinery that only offers $\$ 28 \mathrm{Mg}^{-1}$, net returns for all systems are negative and suggests that producers would not be interesting in growing switchgrass for grazing or bioenergy. With a feedstock price that ranges between $\$ 55$ and $\$ 83 \mathrm{Mg}^{-1}$, livestock producers would earn between $\$ 232$ and $\$ 523 \mathrm{ha}^{-1}$ by grazing lightly and marketing $10.55 \mathrm{Mg} \mathrm{ha}^{-1}$ of residual feedstock. At a price equal to or greater than $\$ 110 \mathrm{Mg}^{-1}$, the NG/F was the most profitable system. This indicates that at these higher prices, the producers would have no incentive to graze; they would only produce and market feedstock for the bioenergy industry. Moreover, for a feedstock price less than $\$ 110 \mathrm{Mg}^{-1}$, the feedstock-only system would not be able to compete with the conventional grazing systems commonly used by producers in the region.

Tables 4 and 5 report how sensitive the base case results are for strong and weak cattle market scenarios. Overall, results from these two cattle market scenarios revealed that the net returns are sensitive to the cattle prices but choice of system is most sensitive to the expected farm-gate price of feedstock. For instance, under the strong cattle market scenario (i.e., $30 \%$ 
Table 3 Estimated net returns for seven switchgrass grazing/ bioenergy feedstock systems for a range of farm gate feedstock prices and base-case values of gain

\begin{tabular}{|c|c|c|c|c|c|c|c|c|}
\hline \multirow{4}{*}{$\begin{array}{l}\text { Price of } \\
\text { feedstock } \\
\left(\$ \mathrm{Mg}^{-1}\right)\end{array}$} & \multicolumn{7}{|c|}{ Value of gain $\left(\$ \mathrm{~kg}^{-1}\right)$} & \\
\hline & 1.75 & 1.55 & 1.29 & 1.75 & 1.55 & 1.29 & - & \\
\hline & \multicolumn{8}{|c|}{ Switchgrass grazing/feedstock system } \\
\hline & $\mathrm{GL} / \mathrm{NF}^{\mathrm{a}}$ & $\mathrm{GM} / \mathrm{NF}^{\mathrm{a}}$ & $\mathrm{GH} / \mathrm{NF}^{\mathrm{a}}$ & $\mathrm{GL} / \mathrm{F}^{\mathrm{b}}$ & $\mathrm{GM} / \mathrm{F}^{\mathrm{b}}$ & $\mathrm{GH} / \mathrm{F}^{\mathrm{b}}$ & $\mathrm{NG} / \mathrm{F}^{\mathrm{b}}$ & $P>\mathrm{F}^{\mathrm{c}}$ \\
\hline 0 & $7 b$ & $45 \mathrm{a}$ & $-26 c$ & - & - & - & $-245 \mathrm{~d}$ & 0.0001 \\
\hline 28 & - & - & - & $-58 b$ & $-5 \mathrm{a}$ & $-74 b$ & $-338 c$ & 0.0001 \\
\hline 55 & - & - & - & $232 \mathrm{a}$ & $218 b$ & $140 \mathrm{c}$ & $85 \mathrm{~d}$ & 0.0004 \\
\hline 83 & - & - & - & $523 \mathrm{a}$ & $442 \mathrm{c}$ & $354 \mathrm{c}$ & $508 \mathrm{~b}$ & 0.0004 \\
\hline 110 & - & - & - & $813 b$ & $666 c$ & $568 \mathrm{~d}$ & $931 \mathrm{a}$ & 0.0001 \\
\hline 165 & - & - & - & $1394 b$ & $1113 c$ & $997 \mathrm{c}$ & $1777 \mathrm{a}$ & 0.0001 \\
\hline
\end{tabular}

Means reported within a row followed by a common letter are not significantly different based on LSD test $(P \leq 0.05)$

$G L / N F$ graze lightly, no feedstock, $G M / N F$ graze moderately, no feedstock, $G H / N F$ graze heavily, no feedstock, $G L / F$ graze lightly plus feedstock, $G M / F$ graze moderately plus feedstock, $G H / F$ graze heavily plus feedstock, $N G / F$ feedstock only system

${ }^{\text {a }}$ Cost of mowing was included in the budget as annual maintenance expense for the three graze-only systems (GL/NF, GM/NF, GH/NF)

${ }^{\mathrm{b}}$ Cost of harvest activities (mowing, raking, baling, and hauling and stacking) were included in "the budget" as annual maintenance expenses for the feedstock-only system (NG/F) and three grazing plus feedstock systems $(\mathrm{GL} / \mathrm{F}, \mathrm{GM} / \mathrm{F}, \mathrm{GH} / \mathrm{F})$

${ }^{\mathrm{c}} P$ values are based on Fisher's protected $F$-tests increase in VOG over the base-case price scenario), the most profitable system assuming a $\$ 0 \mathrm{Mg}^{-1}$ price of feedstock was the moderately grazed, no-feedstock system (GM/NF), the same found at the base cattle price scenario. However, the net return realized under the strong market price scenario was about $\$ 144 \mathrm{ha}^{-1}$ which is $220 \%$ greater than the net return that realized with the base cattle market price scenario for this system with the same feedstock price. Similar results were
Table 4 Net returns for seven switchgrass grazing/bioenergy feedstock systems for a range of feedstock prices $\left(\$ 0 \mathrm{Mg}^{-1}\right.$ $\$ 165 \mathrm{Mg}^{-1}$ ) and values of gain under strong cattle market scenario $(30 \%$ increase in VOG from the base)

\begin{tabular}{|c|c|c|c|c|c|c|c|c|}
\hline \multirow{4}{*}{$\begin{array}{l}\text { Price of } \\
\text { feedstock } \\
\left(\$ \mathrm{Mg}^{-1}\right)\end{array}$} & \multicolumn{7}{|c|}{ Value of gain $\left(\$ \mathrm{~kg}^{-1}\right)$} & \\
\hline & 2.27 & 2.01 & 1.70 & 2.27 & 2.01 & 1.70 & - & \\
\hline & \multicolumn{8}{|c|}{ Switchgrass grazing/feedstock system } \\
\hline & $\mathrm{GL} / \mathrm{NF}^{\mathrm{a}}$ & $\mathrm{GM} / \mathrm{NF}^{\mathrm{a}}$ & $\mathrm{GH} / \mathrm{NF}^{\mathrm{a}}$ & $\mathrm{GL} / \mathrm{F}^{\mathrm{b}}$ & $\mathrm{GM} / \mathrm{F}^{\mathrm{b}}$ & $\mathrm{GH} / \mathrm{F}^{\mathrm{b}}$ & $\mathrm{NG} / \mathrm{F}^{\mathrm{b}}$ & $P>\mathrm{F}^{\mathrm{c}}$ \\
\hline 0 & $95 b$ & $144 \mathrm{a}$ & $53 \mathrm{c}$ & - & - & - & $-245 \mathrm{~d}$ & 0.0001 \\
\hline 28 & - & - & - & $30 \mathrm{~b}$ & $94 \mathrm{a}$ & $5 \mathrm{c}$ & $-338 d$ & 0.0001 \\
\hline 55 & - & - & - & $320 \mathrm{a}$ & $318 \mathrm{a}$ & $219 b$ & $85 \mathrm{c}$ & 0.0004 \\
\hline 83 & - & - & - & $611 \mathrm{a}$ & $541 b$ & $433 c$ & $508 b$ & 0.0004 \\
\hline 110 & - & - & - & $901 \mathrm{a}$ & $765 b$ & $649 \mathrm{c}$ & $931 \mathrm{a}$ & 0.0001 \\
\hline 165 & - & - & - & $1482 b$ & $1212 \mathrm{c}$ & $1076 \mathrm{~d}$ & $1777 \mathrm{a}$ & 0.0001 \\
\hline
\end{tabular}

Means reported within a row followed by a common letter are not significantly different based on LSD test $(P \leq 0.05)$

$G L / N F$ graze lightly, no feedstock, $G M / N F$ graze moderately, no feedstock, $G H / N F$ graze heavily, no feedstock, $G L / F$ graze lightly plus feedstock, $G M / F$ graze moderately plus feedstock, $G H / F$ graze heavily plus feedstock, $N G / F$ feedstock only system

${ }^{a}$ Cost of mowing was included in the budget as annual maintenance expense for the three graze-only systems (GL/NF, GM/NF, GH/NF)

${ }^{\mathrm{b}}$ Cost of harvest activities (mowing, raking, baling, and hauling and stacking) were included in "the budget" as annual maintenance expenses for the feedstock-only system $(\mathrm{NG} / \mathrm{F})$ and three grazing plus feedstock systems $(\mathrm{GL} / \mathrm{F}, \mathrm{GM} / \mathrm{F}, \mathrm{GH} / \mathrm{F})$

${ }^{\mathrm{c}} P$ values are based on Fisher's protected $F$-tests 
Table 5 Net return for seven switchgrass grazing/bioenergy feedstock systems for a range of feedstock prices $\left(\$ 0 \mathrm{Mg}^{-1}-\right.$ $\$ 165 \mathrm{Mg}^{-1}$ ) and values of gain under weak cattle market scenario (30\% reduction in VOG from the base)

\begin{tabular}{|c|c|c|c|c|c|c|c|c|}
\hline \multirow{3}{*}{$\begin{array}{l}\text { Price of } \\
\text { feedstock } \\
\left(\$ \mathrm{Mg}^{-1}\right)\end{array}$} & \multicolumn{7}{|c|}{ Value of gain $\left(\$ \mathrm{~kg}^{-1}\right)$} & \\
\hline & \multicolumn{8}{|c|}{ Switchgrass grazing/feedstock system } \\
\hline & $\mathrm{GL} / \mathrm{NF}^{\mathrm{a}}$ & $\mathrm{GM} / \mathrm{NF}^{\mathrm{a}}$ & $\mathrm{GH} / \mathrm{NF}^{\mathrm{a}}$ & $\mathrm{GL} / \mathrm{F}^{\mathrm{b}}$ & $\mathrm{GM} / \mathrm{F}^{\mathrm{b}}$ & $\mathrm{GH} / \mathrm{F}^{\mathrm{b}}$ & $\mathrm{NG} / \mathrm{F}^{\mathrm{b}}$ & $\mathrm{P}>\mathrm{F}^{\mathrm{c}}$ \\
\hline 0 & $-78 \mathrm{a}$ & $-54 \mathrm{a}$ & $-105 b$ & - & - & - & $-245 \mathrm{~d}$ & 0.0001 \\
\hline 28 & - & - & - & $-143 b$ & $-104 \mathrm{a}$ & $-153 b$ & $-338 c$ & 0.0001 \\
\hline 55 & - & - & - & $148 \mathrm{a}$ & $119 \mathrm{a}$ & $61 b$ & $85 b$ & 0.0004 \\
\hline 83 & - & - & - & $438 b$ & $343 \mathrm{c}$ & $275 d$ & $508 \mathrm{a}$ & 0.0004 \\
\hline 110 & - & - & - & $729 b$ & $566 \mathrm{c}$ & $489 \mathrm{~d}$ & $931 \mathrm{a}$ & 0.0001 \\
\hline 165 & - & - & - & $1310 \mathrm{~b}$ & $1013 \mathrm{c}$ & $918 \mathrm{~d}$ & $1777 \mathrm{a}$ & 0.0001 \\
\hline
\end{tabular}

Means reported within a row followed by a common letter are not significantly different based on LSD test $(P \leq 0.05)$

$G L / N F$ graze-lightly, no feedstock, $G M / N F$ graze-moderately, no feedstock, $G H / N F$ graze-heavily, no feedstock, $G L / F$ graze lightly plus feedstock, $G M / F$ graze moderately plus feedstock, $G H / F$ graze-heavily plus feedstock, $N G / F$ feedstock only system

${ }^{a}$ Cost of mowing was included in the budget as annual maintenance expense for the three graze-only systems (GL/NF, GM/NF, GH/NF)

${ }^{\mathrm{b}}$ Cost of harvest activities (mowing, raking, baling, and hauling and stacking) were included in "the budget" as annual maintenance expenses for the feedstock-only system (NG/F) and three grazing plus feedstock systems $(\mathrm{GL} / \mathrm{F}, \mathrm{GM} / \mathrm{F}, \mathrm{GH} / \mathrm{F})$

${ }^{\mathrm{c}} P$ values are based on Fisher's protected $F$-tests observed under a weak cattle price scenario (30\% reduction in VOG from the base case cattle price) as net return reduced by $220 \%$ for the most profitable system (GM/NF) at the $\$ 0 \mathrm{Mg}^{-1}$ feedstock price.

Three overarching assumptions central to this paper are (1) that agricultural producers would be directly involved in the establishment, annual maintenance, and harvesting (cutting, raking, baling, and stacking) switchgrass bioenergy feedstock; (2) cattle producers might be able to establish, manage, and flash graze switchgrass pastures as a way to extend the coolseason cereal forage graze-only production system common in the SGP; and (3) that producers would be able to market their bioenergy feedstock in a spot market similar to other agricultural commodities such as corn, cattle, and cotton. It is important that we point out that there are competing theories about how the cellulosic farm-to-fuel business might be structured to bring about the most economically efficient solution for using scarce land, labor, and capital resources in the SGP while at the same time maximizes the profitability from producing bioenergy products such as ethanol.

In their publication, Epplin et al. [9] point out that a spot market for switchgrass feedstock has not developed and developing such a market could face serious challenges due to harvest and transportation costs from the field to the refinery. They also provide descriptions and economics of two alternative switchgrass acquisition methods that would likely be more cost efficient, less financially risky than a farmer spot market. The first method would be for the refinery to engage in land leases for switchgrass acres needed to supply a large-scale refinery. The second method would be to engage in production contracts with farmers to establish, maintain, and harvest switchgrass feedstock. The land lease structure would essentially take the farmer out of the decision-making and production process, other than establishing switchgrass. The production contract method allows farmers to provide bids to the refiner to grow; maintain; and cut, rake, bale, and stack switchgrass feedstock near a truck-accessible road. The bid would have two payment components: a base payment quoted in $\$$ $\mathrm{ha}^{-1}$ and an incentive component quoted in $\$ \mathrm{Mg}^{-1}$. A key benefit to the land lease method is it allows for an 8-month harvest season, where the contract method allows for a 2-month harvest window.

Epplin and his colleagues [9] report for each method the expected total cost of a delivered metric ton feedstock $(\$$ $\mathrm{Mg}^{-1}$ ) to a large-scale refinery that would require $1814 \mathrm{Mg}$ of dry switchgrass feedstock each day for 350 days per year. These costs are $\$ 53.86$ and $\$ 71.97 \mathrm{Mg}^{-1}$ for land lease (8-month harvest season) and production contract (2-month harvest season) methods, respectively. To provide some perspective to their findings, the findings in our study suggests that it would cost between $\$ 50$ and $71 \mathrm{Mg}^{-1}$ to establish, maintain, harvest, and stack switchgrass near a truckaccessible road. This cost does not include transportation to a refinery, which can be as much as $\$ 2.5 \mathrm{~km}^{-1}$ in the current marketplace. If the distance to a refinery is equal to $160 \mathrm{~km}$, then the transportation cost would be an additional $\$ 17 \mathrm{Mg}^{-1}$, putting our range at $\$ 67$ to $\$ 88 \mathrm{Mg}^{-1}$, delivered. These 
rates are similar to those reported by Epplin and his colleagues for the production contract method that is based on farmers submitting bids to refineries for delivery of switchgrass feedstock. Based on this estimate, it would be interesting and important to extend the work outlined in this paper to incorporate our production data and estimated costs into the model developed by Tembo, Epplin, and Huhnke [10] to evaluate the economic potential of using stocker cattle to flash graze tender, high-quality switchgrass in late spring (May through June) and enter into a production contract to sell the harvested regrowth as bioenergy feedstock to a hypothetical large-scale biorefinery located in the region.

\section{Conclusions}

Information regarding the potential economic feasibility of using switchgrass to grow cattle and bioenergy feedstock is limited. Three years of data collected from a grazing study conducted in south-central Oklahoma were used to evaluate the economics of seven alternative grazing, bioenergy feedstock, or grazing and bioenergy feedstock systems that could serve to extend the small grain pasture graze-out system common to the Southern Great Plains. The results indicate that producers could earn a positive net return by extending the cereal forage grazing season by grazing switchgrass with moderate grazing pressure during the interim phase of industry development (i.e., feedstock price equal to $\$ 0 \mathrm{Mg}^{-1}$ ). The results also suggest that if a biorefinery offered farm gate prices from $\$ 55$ to $\$ 83 \mathrm{Mg}^{-1}$, it would be economical for producers to graze switchgrass with moderate grazing pressure and harvest and market residual feedstock. At a price equal to or greater than $\$ 110 \mathrm{Mg}^{-1}$, producers would benefit by only producing and marketing bioenergy feedstock. Results revealed that the net returns for all systems were sensitive to the expected value of beef gain but was most sensitive to the expected farm-gate price of bioenergy feedstock. Our results hinge entirely on the assumption that producers can sell their bioenergy feedstock on a spot market similar to other commodities such as corn and cattle. Future research would be required to determine if it would be economically feasible to incorporate the grazing/ feedstock activity outlined in this paper into a large-scale vertically integrated bioenergy industry business model.

Acknowledgments This research was funded by the USDA-NIFA, USDA-DOE Biomass Research and Development Initiative, Grant No. 2009-10006-06070. The authors are sincerely grateful to Wallace Tyner for his efforts in managing the review of this manuscript and kindly thank two anonymous reviewers for their valuable comments and suggestions the certainly led to the improvement of our paper.

Open Access This article is distributed under the terms of the Creative Commons Attribution 4.0 International License (http:// creativecommons.org/licenses/by/4.0/), which permits unrestricted use, distribution, and reproduction in any medium, provided you give appropriate credit to the original author(s) and the source, provide a link to the Creative Commons license, and indicate if changes were made.

\section{References}

1. Butler TJ, Biermacher JT, Kering MK, Interrante SM (2012) Production and economics of grazing steers on rye-annual ryegrass with legumes or fertilized with nitrogen. Crop Sci 52(4):1931-1939

2. Beck PA, Gunter SA, Lusby KS, West CS, Watkins KB, Hubbell DS III (2008) Animal performance and economic comparison of novel and toxic endophyte tall fescues to cool season annuals. J Anim Sci 86:2043-2055

3. Luis P (2005) Filling the Southern Plains forage gap. Agricultural research magazine. U.S. Department of Agriculture. Agricultural Research Service 12:18-19

4. Coulibaly N, Bernardo DJ, Horn GW (1996) Energy supplementation strategies for wheat pasture stocker cattle under uncertain forage availability. J Agri Appl Econ 1:172-179

5. Rao SC, Northup BK, Mayeux HA (2005) Candidate cool-season legumes for filling forage deficit periods in the southern Great Plains. Crop Sci 5:2068-2074

6. Epplin FM, Hossain I, Krenzer EG (2000) Winter wheat fall-winter forage yield and grain yield response to planting date in a dualpurpose system. Ag Sys 63:161-173

7. Peel DS (2006) Economics of stocker production. Vet Clin N Am Food Anim Pract 22:271-296

8. Peel DS (2012) Maintaining competitiveness with today's high grain prices. Iowa Beef Center. http://www.iowabeefcenter.org/ proceedings/MaintainingCompetitiveness.pdf. Accessed 2 January 2015

9. Epplin FM, Clark CD, Roberts RK, Hwang S (2007) Challenges to the development of a dedicated energy crop. Amer J Agri Econ 5: 1296-1302

10. Tembo G, Epplin FM, Huhnke RL (2003) Integrative investment appraisal of a lignocellulosic biomass-to-ethanol industry. J Agri Res Econ 3:611-633

11. Haque M, Biermacher JT, Kering M, Guretzky JA (2013) Economics of alternative fertilizer supply systems for switchgrass produced in phosphorus-deficient soils for bioenergy feedstock. Bioenergy Res 1:351-357

12. Haque M, Biermacher JT, Kering MK, Guretzky JA (2014) Economic evaluation of switchgrass feedstock production systems tested in potassium-deficient soils. Bioenergy Res 1:260-267

13. Sladden SE, Bransby DI, Aiken GE (1991) Biomass yield, composition and production costs for eight switchgrass varieties in Alabama. Biomass Bioenergy 2:119-122

14. Sanderson MA, Read JC, Reed RL (1999) Harvest management of switchgrass for biomass feedstock and forage production. Agron J $1: 5-10$

15. Kering MK, Biermacher JT, Twain TJ, Mosali J, Guretzky JA (2012) Biomass yield and nutrient responses of switchgrass to phosphorus application. Bioenergy Research 1:71-78

16. Burns JC, Mochrie RD, Timothy DH (1984) Steer performance from two perennial Pennisetum species, switchgrass, and a fescue - "costal bermudagrass system". Agron J 5:795-800

17. Mosali J, Biermacher JT, Cook BJ, Blanton J (2013) Bioenergy for cattle and cars: a switchgrass production system that engages cattle producers. Agron J 4:960-966

18. Hintz RL, Moore KJ, Tarr AB (2002) Cropping systems research for biomass energy production. Iowa State University, Ames, pp 54. A final report prepared for the Chariton Valley Resource Conservation and Development, Inc. 
19. Lowe JK (2013) The economics of grazing beef and dairy cattle on native warm-season grasses in Tennessee. Master's Thesis, University of Tennessee

20. Lawrence J, Cherney J, Barney P, Ketterings Q (2006) Establishment and management of switchgrass Cornell University Cooperative Extension, Ithaca, NY. http://forages.org/bioenergy/downloads/ Switchgrassfactsheet20.pdf. Accessed 15 October 2013

21. Sanderson MA, Reed RL, Ocumpaugh WR, Hussey MA, Esbroeck GV, Read JC, Tischler CR, Hons FM (1999) Switchgrass cultivars and germplasm for biomass feedstock production in Texas. Bioresour Technol 67(3):209-219

22. Fuentes RG, Taliaferro CM (2002) Biomass yield stability of switchgrass cultivars. In: Janick J, Whipkey A (eds) Trends in new crops and new uses. ASHS Press, Alexandria, pp 276-282

23. Guretzky JA, Biermacher JT, Cook B, Kering M, Mosali J (2011) Switchgrass for forage and bioenergy: harvest and nitrogen rate effects on biomass yields and nutrient composition. Plant Soil 339(1):69-81

24. American Agricultural Economics Association. AAEA (2000) Commodity costs and returns estimation handbook. A report of the AAEA task force on commodity costs and returns. Ames

25. Interrante SM, Biermacher JT, Kering MK, Butler TJ (2012) Production and economics of steers grazing tall fescue with annual legumes or fertilized with nitrogen. Crop Sci 52(4): 1940-1948

26. Haque M, Epplin FM, Taliaferro CM (2009) Nitrogen and harvest frequency effect on yield and cost of four perennial grasses. Agron J 101(6):1463-1469

27. Doye D, Sahs R (2010) Oklahoma farm and ranch custom rates, 2009-2010. Oklahoma State University, Oklahoma Cooperative Extension Service, CR-205 (0310 Rev)

28. Peel DS (2013) Winter stocker opportunities in today's cattle market. Drovers. Farm Journal, Inc. http://www.cattlenetwork.com/ cattle-news/Winter-stocker-opportunities-in-todays-cattle-market228644781.html. Accessed 6 December 2016
29. BeefBasis.com (2011) Feeder cattle basis forecast http://www. beefbasis.com/ForecastingTools/ValueofGain/tabid/1132/Default. aspx. Accessed 2 January 2013

30. Mooney DF, Roberts RK, English BC, Tyler DD, Larson JA (2008) Switchgrass production in marginal environments: a comparative economic analysis across four West Tennessee landscapes. American Agricultural Economics Association Annual Meeting, Orlando

31. Boyer CN, Tyler DD, Roberts RK, English BC, Larson JA (2012) Switchgrass yield response functions and profit-maximizing nitrogen rates on four landscapes in Tennessee. Agron J 104(6):1579-1588

32. Epplin FM (1996) Cost to produce and deliver switchgrass biomass to an ethanol-conversion facility in the southern plains of the United States. Biomass Bioenergy 11:459-467

33. Bangsund DA, DeVuyst EA, Leistritz FL (2008) Evaluation of breakeven farm-gate switchgrass prices in south central North Dakota. North Dakota State University; Agribusiness and Applied Economics Report No.: 632-S, Fargo, pp 1-12

34. Mooney DF, Roberts RK, English BC, Tyler DD, Larson JA (2009) Yield and breakeven price of 'Alamo' switchgrass for biofuels in Tennessee. Agron J 101(5):1234-1242

35. Littell RC, Milliken GA, Stroup WW, Wolfinger RD (1996) SAS system for mixed models. SAS Inst, Cary

36. SAS Institute (2008) SAS/STAT. SAS system for windows. v. 9.2. SAS Inst, Cary

37. Greene WH (2008) Econometric analysis. Hypothesis and specification tests and fit measures, 6th edn. Pearson Education, Inc., Upper Saddle River, pp 498-500

38. Butler TJ, Biermacher JT, Interrante SM, Sledge MK, Hopkins AA, Bouton JH (2012) Production and economics of grazing alfalfa in the southern Great Plains. Crop Sci 52(3):1424-1429

39. Anderson B, Ward JK, Vogel KP, Ward MG, Gorz HJ, Haskins FA (1988) Forage quality and performance of yearlings grazing switchgrass strains selected for differing digestibility. J Anim Sci 66: 2239-2244

40. Griffin JL, Jung GA (1983) Leaf and stem forage quality of big bluestem and switch grass. Agron J 75:723-726 